"Comparison of the impact of lending and inflation rates on economic growth in Vietnam and China"

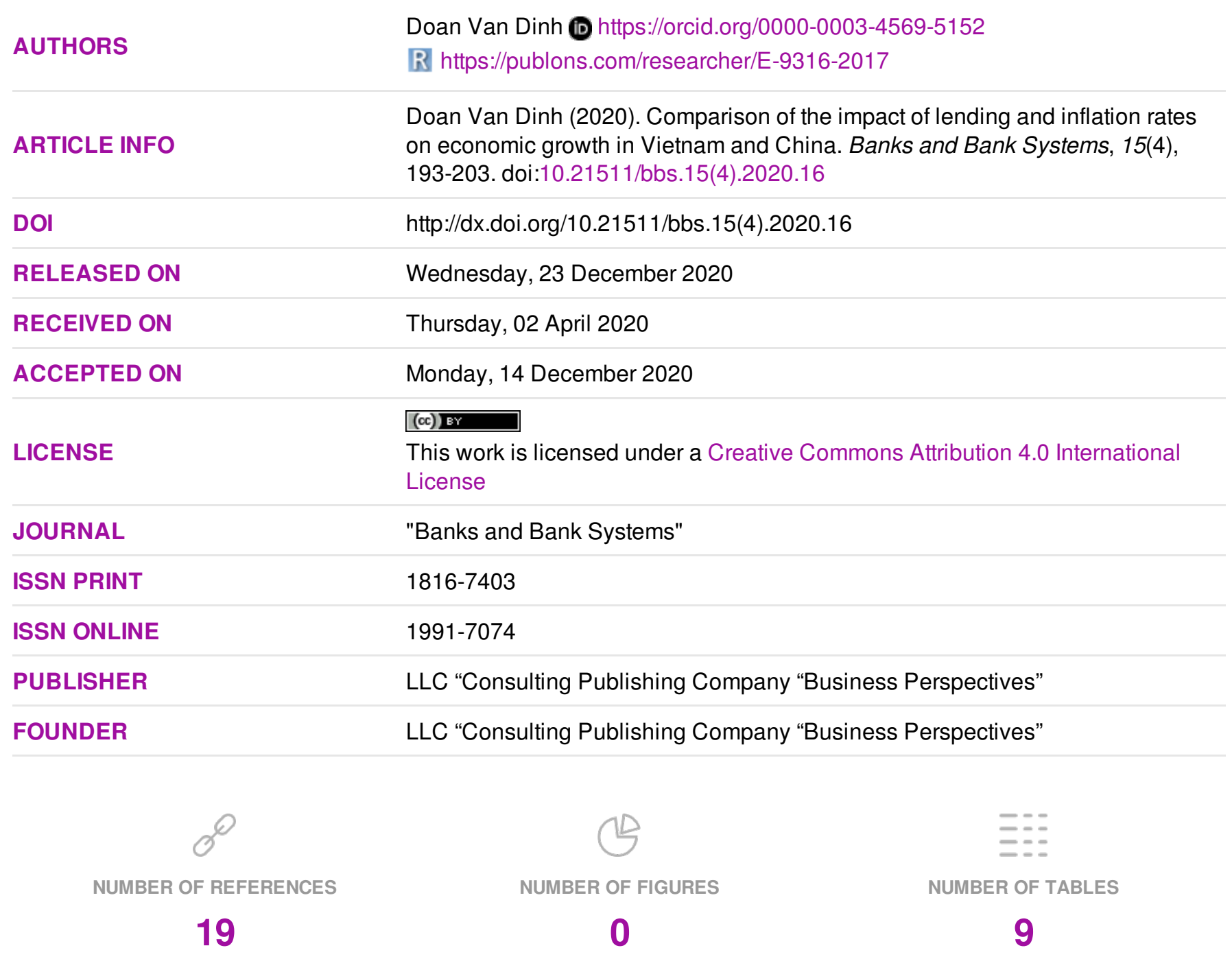

(C) The author(s) 2021. This publication is an open access article. 


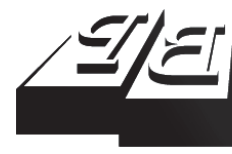

BUSINESS PERSPECTIVES

(O)

LLC "CPC "Business Perspectives" Hryhorii Skovoroda lane, 10, Sumy, 40022, Ukraine www.businessperspectives.org
Received on: $2^{\text {nd }}$ of April, 2020 Accepted on: $14^{\text {th }}$ of December, 2020 Published on: $23^{\text {rd }}$ of December, 2020

๑) Doan Van Dinh, 2020

Doan Van Dinh, Ph.D., Faculty of Finance and Banking, Industrial University of Ho Chi Minh City, Vietnam.

\section{COMPARISON OF THE IMPACT OF LENDING AND INFLATION RATES ON ECONOMIC GROWTH IN VIETNAM AND CHINA}

\begin{abstract}
Inflation and lending rates are two important macroeconomic indicators as they affect economic growth. The correlation between the inflation rate and the lending rate in Vietnam and China is analyzed to determine whether the lending rate causes inflation or not. An ordinary least square model (OLS) and a unit root test are applied to check the correlation and cointegration related to the inflation and lending rates to avoid spurious regression. The research time series data were collected from 1996 to 2017. The correlation of Vietnam's variables is $56 \%$, the correlation of China's variables is $55 \%$, which is a close correlation. The empirical cointegration test results for Vietnam and China are suitable for two research models. The relationship between these two indicators influences each other. In the short term, inflation stimulates economic growth through loose monetary policy through the lending rate. However, in the long term, if the money supply increases continuously, inflation will slow economic growth and increase bad debt. The empirical results are to make accurate forecasts and determine monetary policy for micro-managers who set the goal of sustainable economic growth and have a strategy for economic development in the short and long term.
\end{abstract}

Keywords money, crisis, debt, recession, GDP, development

JEL Classification E47, E52, E43, C53

\section{INTRODUCTION}

The stability of economies around the world is a goal of controlling inflation through the lending rate. Therefore, some authors have investigated the correlation between inflation and interest rates as the basis for the adoption of fiscal and monetary policies to promote an effective economy. They showed a positive correlation between inflation and interest rate variables (Khumalo et al., 2017). Another study investigated the correlation between inflation and lending rates and revealed that inflation affected lending rates of commercial banks. Chowdhury (2012) used the Dickey-Fuller test for inflation and lending interest rates and showed that there was no significant relationship between them. Irving Fisher, American economist, also indicated that the inflation rate and real and nominal interest rates correlated together. Therefore, the real rate fell as inflation rose, unless the nominal rate increased at the same rate as inflation (Mishkin, 2016). Hence, they related closely to each other. In other words, the nominal interest rate and the inflation rate had a positive relationship. Also, there was research on inflation rate and interest rate variables that affected economic growth. In long run, the studies showed causality between economic growth and inflation, and there also exists a unidirectional causal movement from economic growth to interest rate. To study this, correlation, augmented Dickey-Fuller test (ADF), 
unit root tests, cointegration test, error vector correction model and a Granger causality test were applied (Amalendu, 2016).

These studies showed that the authors found the correlation between inflation rate and interest rate, and the results were obtained using econometric or statistical methods. Although the results suggested that the relationship was positive or negative, the two indices affect economic growth. However, these results were of research value only for each specific research object in each country.

A linear regression model and a cointegration test are applied to evaluate whether the change of lending rate affects inflation rate or not. And how does it affect? The research results show that changes in lending interest rates in Vietnam and China affect inflation. Moreover, the cointegration test is applied to avoid a spurious regression model. Spurious regression models are explained in the methodology section.

\section{LITERATURE REVIEW}

According to Friedman, inflation is always a monetary phenomenon everywhere. This means that if the money supply growth is extremely high for a period, the country's inflation rate is also extremely high. It is necessary to have monetary policy tools to control money supply in circulation for relevant money demand. Keynes's liquidity preference theory showed that the transactions motive, the precautionary motive and the speculative motive affected money demand. However, the factors influencing the decision of how much money to keep for the transactions motive, are interest rates. This showed that when interest rates grow, money demand decreases, and therefore money demand is negatively related to interest rates, that is, an increase in money demand leads to an increase in money supply when that influences inflation (Mishkin, 2016).

Inflation and interest rates were studied in the literature that showed a positive correlation between interest rate and economic growth. However, some other findings showed a negative relationship, such as Hamidah and Mohd (2017) in Malaysia. Besides, some studies revealed that interest rates drive inflation in the dynamic economy. Tillmann (2008) used an empirical method to assess the cost of monetary transmission related to inflation. It was shown that the higher interest rate shifted into the higher marginal costs of production, and eventually, into the higher inflation, i.e. interest rate affected inflation through high interest rate cost. It was understood that inflation was due to additional costs. The topic was about raising rates to raise inflation, in the short run, the increased target inflation was increasing, the nominal interest rate was required. The result showed that the nominal interest rate and inflation rates were positively related. However, the authors didn't show their relationship in the long run (Garín et al., 2016). Indicators of inflation, interest and exchange rates are factors that affect economic growth, but each factor had an impact on different economic growth. Moreover, these factors could also interact together. Hence, the authors established these relationships to assess the impact of these variables by the regression model; it was shown that they affected each other (Moroşan \& Zubaş, 2015). Besides, a study of inflation and interest rates also indicated that they had a positive correlation, i.e., an increased interest rate caused an increase in production costs and, as a result, the level of prices and inflation rate increased (Aimal \& Meetra, 2018). Kaplan and Gungor (2017) used a VAR model to study the effect of inflation rate, economic growth, money supply, and interest rate. It was shown that interest rates or money supply were changed that affected inflation. In addition, some literature mentioned inflation, interest rates, stock prices and economic growth. The authors had the same point of view that they had a close relationship with each other (Apergis \& Eleftheriou, 2002; Jiménez et al., 2012; Berument et al., 2005; Kamal et al., 2015).

Upon the arguments, the inflation rate and interest rate have a causal relationship. Based on the obtained results, inflation and interest rates have a positive causal relationship and affect economic growth, such as lending rate and deposit rate. 
The literature applied statistical and econometric methods to analyze the relationship between these variables (Dinh, 2019b).

It was known that most literature applied a regression method and some method tests. Moreover, the literature has limited data analysis only within the scope of a country, so this paper also applies the OLS model and some other tests to estimate and forecast the inflation rate and lending rate in Vietnam. The research results were suitable only for a specific scope of research. Thus, this study focuses on the analysis of two factors, such as inflation and lending rate, to consider whether the lending rate affects inflation rate or not? The study the OLS model for Vietnam's lending rate and inflation rate data to analyze their correlation.

\section{METHODOLOGY AND HYPOTHESES DEVELOPMENT}

The basic lending rate is the interest rate when borrowers borrow money from commercial banks, and loan rates are determined based on the Central bank's lending rate. Lending rates are very important because they affect the liquidity of the stock market, investment sectors and GDP growth. Low lending rates will increase liquidity because loans from banks are cheap and, therefore, borrowers will be more willing to borrow. Besides, when lending rates are low, businesses will borrow much to expand their size, and the economy will grow. Similarly, when interest rates are high, the economy is less liquid and economic growth will also slow down. As is known, low lending rates mean that banks supply money quantities in circulation, but the money supply is too much or the supply shock leads to an inflated economy. For this reason, the forecasting model of lending rates and inflation is necessary to control inflation and GDP growth. Inflation is defined as a continuous and rapid rise in the price level.

$$
\pi=\% \Delta M-\% \Delta Y,
$$

where $\% \Delta M=\frac{M_{i}-M_{i-1}}{M_{i-1}} \cdot \%$ and

$$
\% \Delta Y=\frac{Y_{i}-Y_{i-1}}{Y_{i-1}} \cdot \%
$$

Formula (1) shows that there are three hypotheses: $\% \cdot \Delta M>\% \cdot \Delta Y, \pi$ increases, leading to inflation in the economy, $\% \cdot \Delta M=\% \cdot \Delta Y$. $\pi$ does not increase nor decrease (zero), the inflation in the economy is zero. $\% \cdot \Delta M<\% \cdot \Delta Y, \pi$ decreases under zero level, leading to the deflation in the economy. This shows that inflation is caused by currency. However, the hypothesis on $\% \cdot \Delta M>\% \cdot \Delta Y$ will cause inflation, but if it is at an optimum threshold, it promotes economic growth, and vice versa.

The nominal interest rate is not adjusted by the inflation rate, so it must be adjusted to more accurately reflect the real cost of borrowing. Thus, the Fisher equation showed that the nominal interest rate $(i)$ equals the real interest rate $(r)$ plus the expected rate of inflation $\left(\pi^{e}\right)$. The real interest rate is very important to economic decisions; it is what economists mean when they make reference to the real interest rate. The interest rate adjusted for actual changes in the price level is called the expected real interest rate. To analyze the impact of lending rate on inflation, the questions need to be identified as follows: Is the model considered a spurious linear model or not? Are the two variables correlated or not? Do the forecast model results show the relevance between the lending rate and economic growth or not? How does the lending rate cause both inflation and bad debt rates and regulate them? In the study, the correlation between the inflation rate and lending rate in Vietnam is considered whether they have positive or negative and linear or nonlinear relationship. So, the study uses the following econometrics model for analysis (Dinh, 2020c).

The equation is written as follows:

$$
y_{t, \text { Inf }}=\beta_{1}+\beta_{2} X_{t, \text { Lending }}+\varepsilon_{t} .
$$

Equation (2) is written as an OLS model:

$$
\widehat{y_{t, \text { Inf }}}=\widehat{\beta_{1}}+\widehat{\beta_{2}} X_{t, \text { Lending }}+\varepsilon_{t},
$$

where $\widehat{y_{t, \operatorname{lnf}}}$ is an independent variable of the inflation rate, $t=1$ th $22 ; X_{t, \text { Lending }}$ is a dependent variable of the lending rate, $t=1$ th 22 
$\varepsilon_{t}=y_{t, \text { Inf }}-\widehat{y_{t, \text { Inf }}}=y_{t, \text { Inf }}-\left(\widehat{\beta_{1}}+\widehat{\beta_{2}} X_{t, \text { Lending }}\right)$,

where $\widehat{\beta}_{1}, \widehat{\beta}_{2}$ are unknown constants that estimate how the sum of error squares $\left(\varepsilon_{t}\right)$ is the least. i.e.,

$\sum_{t=1}^{22} \varepsilon_{i}^{2}=\sum_{t=1}^{22}\left(y_{t, \text { Inf }}-\left(\widehat{\beta}_{1}+\widehat{\beta}_{2} X_{t, \text { Lending }}\right)\right)^{2} \rightarrow \min$.

Why is cointegration applied? That is a spurious regression phenomenon that indicates a non-existing relationship as:

The first case: The coefficient estimate that does not converge to zero. Instead, it follows a non-degenerate distribution.

The second case: Most t-values are often significant.

The third case: $R^{2}$ is typically very high, but the phenomenon of spurious regression has an indication of Durbin-Watson statistics that is low. It is known that the autocorrelation in the residuals or prediction errors is determined by the DurbinWatson statistic in a regression analysis. However, the study does not apply the Durbin-Watson test statistic but used cointegration test to analyze the relationship between inflation and lending rate variables and their impact on the model (Dinh, 2019a).

The Fisher equation also implies cointegration between inflation and nominal interest rates. So, the cointegration test is applied between inflation and nominal lending rates in case of Vietnam's and China's economy. It is known, the definition in the simple case of two time series that are $X_{t, \text { Lending }}$ and $Y_{t, \text { Inf }}$ with $t=1$ th 22 observes that they are both order of integration one (this is abbreviated I(1) that is the 1-degree difference, and means that the process contains a unit root).

Equation (2) is written as follows: $\varepsilon_{t}=Y_{t, \text { Inf }}-\beta_{2} \cdot X_{t, \text { Lending }}$, where $\beta_{2}$ is a stationary process. Let $Y_{t, \text { Inf }}$ and $X_{t, \text { Lending }}$ be cointegrated if there exists a vector when $Y_{t, \text { Inf }}$ and $X_{t, \text { Lending }}$ are in equilibrium. The reason for unit roots and cointegration tests is to avoid spurious regression. Moreover, cointegration is also determined by common trends of the two variables as follows:

$$
\begin{aligned}
& Y_{t, \text { Inf }}=\beta_{1+} \beta_{\mathrm{t}} \cdot t_{+} \varepsilon_{t, \text { Inf }} \\
& \text { and } X_{t, \text { Lending }}=\beta_{1+} \beta_{\mathrm{t}} \cdot t_{+} \varepsilon_{t, \text { Lending }}
\end{aligned}
$$

where $\varepsilon_{t, \text { Inf },}\left(t=1\right.$ th 22) and $\varepsilon_{t, \text { Lending }}(t=1$ th 22) are white noise processes.

Equation (5) is to consider a lag of two variables, that is $Y_{t, \text { Inf }}$ and $X_{t, \text { Lending }}$ by the d-degree difference equation $(\mathrm{I}(\mathrm{d}))$. In this case, two independent random walk processes have the common lag, the two variables are considered cointegrated, that is, they have a real relationship. Otherwise, the linear combination of $Y_{t, \text { Inf }}$ and $X_{t, \text { Lending }}$ must involve random walks $\varepsilon_{t, \text { Lending }}$ and $\varepsilon_{t, \text { Inf }}\left(\varepsilon_{t, \text { Lending }}=\varepsilon_{t, \text { In }}\right)$, and two variables must have a common trend. Moreover, the hypothesis is that $H_{0}$ is a non-cointegration model and $H_{1}$ is a cointegration model, to reject or accept $H_{0}$, it is based on a comparison between the trace Statistic and Critical Value. If trace statistic is smaller than Critical Value, the $H_{0}$ hypothesis is accepted. If trace Statistic is larger than Critical Value, the $H_{0}$ hypothesis is rejected. However, to determine cointegration of the model, it is tested by first unit root to determine if it is lag and trend. Hence, model (3) is tested by unit root as follows:

$$
\left\{\begin{array}{c}
\widehat{y_{t, \text { Inf }}}=\sigma y_{t-1}+\varepsilon_{t} \\
\widehat{X_{t, \text { Lending }}}=\sigma X_{t-1}+\omega_{t}
\end{array},\right.
$$

where $(-1 \leq \sigma \leq 1)$.

There are the following hypotheses:

$H_{0} / \sigma=1\left(y_{t, \text { Inf }}\right.$ and $X_{t, \text { Lending }}$, the time series is non-stationary), i.e. a non-stationary series is one whose statistical properties change over time.

$H_{0} / \sigma<1\left(y_{t, \text { Inf }}\right.$ and $X_{t, \text { Lending }}$, the time series is stationary), i.e. stationary time series is one whose statistical properties such as the mean, variance and autocorrelation are all constant over time. Hereby, equation (6) is estimated by three hypotheses as follows:

$$
\left\{\begin{array}{c}
\Delta y_{t, \text { Inf }}=\sigma y_{t-1, n f}+\varepsilon_{t} \\
\Delta X_{t, \text { Lending }}=\sigma X_{t-1}+\omega_{t}
\end{array},\right.
$$

when $y_{t, \text { Inf }}$ and $X_{t, \text { Lending }}$ walk randomly and have no constants (Dickey-Fuller, DF 1). 


$$
\left\{\begin{array}{c}
\Delta y_{t, \text { Inf }}=\beta_{1}+\sigma y_{t-1, n f}+\varepsilon_{t} \\
\Delta X_{t, \text { Lending }}=\beta_{1}+\sigma X_{t-1}+\omega_{t}
\end{array},\right.
$$

when $y_{t, \text { Inf }}$ and $X_{t, \text { Lending }}$ walk randomly and have constants (Dickey-Fuller, DF 2).

$$
\left\{\begin{array}{c}
\Delta y_{t, \text { Inf }}=\beta_{1}+\beta_{2} \text { time }+\sigma y_{t-1, n f}+\varepsilon_{t} \\
\Delta X_{t, \text { Lending }}=\beta_{1}+\beta_{2} \text { time }+\sigma X_{t-1}+\omega_{t}
\end{array},\right.
$$

when $y_{t, \text { Inf }}$ and $X_{t, \text { Lending }}$ walk randomly and have constants that follow the trend (Dickey-Fuller, DF 3). However, to ensure the appropriateness of the model, an alternative formulation of the ADF test regression is:

$$
\left\{\begin{array}{c}
\Delta y_{t, \text { Inf }}=\beta_{1}+\beta_{2} \text { time }+\sigma_{i} y_{t-1, n f}+ \\
\propto_{i} \sum_{i=1}^{n} \Delta y_{t-i, n f}+\varepsilon_{t} \\
\Delta X_{t, \text { Lending }}=\beta_{1}+\beta_{2} \text { time }+\sigma_{i} X_{t-1, \text { Lending }}+ \\
+\propto_{i} \sum_{i=1}^{n} X_{t-i, \text { Lending }}+\omega_{t}
\end{array}\right.
$$

where $y_{t, \text { Inf }}$ and $X_{t, \text { Lending }}$ are the variable of choice: $\Delta$ is the first-difference operator; $\sigma_{i}(i=1$ and 2$)$, $\propto_{i}(i=1,2 \ldots p)$ and $\beta$ are constant parameters; $\varepsilon_{t}$ and $\omega_{t}$ are a stationary stochastic process $\left(\varepsilon_{t}\right.$ and $\omega_{t}$ are white noise), $p$ is the lag number Dinh (2020a).

As mentioned above, the major objective of the paper is to analyze and evaluate the correlation between the inflation rate and lending rate. Therefore, the following hypotheses are put forward:

$H_{0}$ : The inflation rate and lending rate in Vietnam and China are not correlated with each other.

$H_{1}$ : The inflation rate and lending rate in Vietnam and China are correlated with each other.

The most well-known measure is called determination coefficient or R-square $\left(R^{2}\right)$. This measure is defined in the following way:

$$
R^{2}=\frac{\left(\sum_{i=1}^{18} X_{i, \text { lending }} Y_{i, \text { inf }}\right)^{2}}{\sum_{i=1}^{18} x_{i, \text { lending }}^{2} \sum_{i=1}^{18} y_{i, \text { inf }}^{2}}=1-\frac{R S S}{T S S} .
$$

It is said that 1 is the percentage of the sample variation in $Y_{t, \text { Inf }}$ explained by $X_{t, \text { Lending }}$. According to the definition of $R$ ), the following must be accomplished: $0 \leq R^{2} \leq 1$.

The correlation coefficient is from -1 to 1 . The correlation coefficient equals 0 (or approximately equals 0 ) i.e. the two variables are not related to each other. Conversely, if the coefficient is -1 or 1 , the two variables have an absolute relationship. If the value of the correlation coefficient is negative $(r<0)$, when $X_{t, \text { Lending }}$ increases, $Y_{t, \text { Inf }}$ decreases (and vice versa, when $X_{t, \text { Lending }}$ decreases $Y_{t, \text { Inf }}$ increases). If the correlation coefficient is positive ( $r$ $>0$ ), this means that when $X_{t, \text { Lending }}$ increases, then $Y_{t, \text { Inf }}$ also increases and $Y_{t, \text { Inf }}$ decreases, $X_{t, \text { Lending }}$ also decreases. The methodology is applied to analyze and forecast the impact level of lending capital on inflation through the monetary policy of Vietnam and China (Dinh, 2020b).

Data was collected from the World Development Index (WDI), which is the World Bank's main development indicators dataset and is compiled from official international sources. It provides accessible and accurate data on current global development.

\begin{tabular}{|c|c|c|c|c|c|c|c|c|c|}
\hline 1996 & 20.1 & 5.67 & 10.08 & 8.31 & 2007 & 11.2 & 8.30 & 7.47 & 4.82 \\
\hline 1997 & 14.4 & 3.21 & 8.64 & 2.79 & 2008 & 15.8 & 23.12 & 5.31 & 5.93 \\
\hline 1998 & 14.4 & 7.27 & 6.39 & -0.77 & 2009 & 10.1 & 7.05 & 5.31 & -0.73 \\
\hline 1999 & 12.7 & 4.12 & 5.85 & -1.40 & 2010 & 13.1 & 8.86 & 5.81 & 3.18 \\
\hline 2000 & 10.6 & -1.71 & 5.85 & 0.35 & 2011 & 17.0 & 18.68 & 6.56 & 5.55 \\
\hline 2001 & 9.42 & -0.43 & 5.85 & 0.72 & 2012 & 13.5 & 9.09 & 6.00 & 2.62 \\
\hline 2002 & 9.06 & 3.83 & 5.31 & -0.73 & 2013 & 9.63 & 6.59 & 6.00 & 2.62 \\
\hline 2003 & 9.48 & 3.22 & 5.31 & 1.13 & 2014 & 8.16 & 4.71 & 5.60 & 1.92 \\
\hline 2004 & 9.72 & 7.76 & 5.58 & 3.82 & 2015 & 6.96 & 0.88 & 4.35 & 1.44 \\
\hline 2005 & 11.0 & 8.28 & 5.58 & 1.78 & 2016 & 6.96 & 3.24 & 4.35 & 2.00 \\
\hline 2006 & 1.2 & 7.39 & 6.12 & 1.65 & 2017 & 7.40 & 3.52 & 4.35 & 1.59 \\
\hline
\end{tabular}

Table 1. Lending interest and inflation rates (unit \%)

Source: World Bank's World Development Indicators.

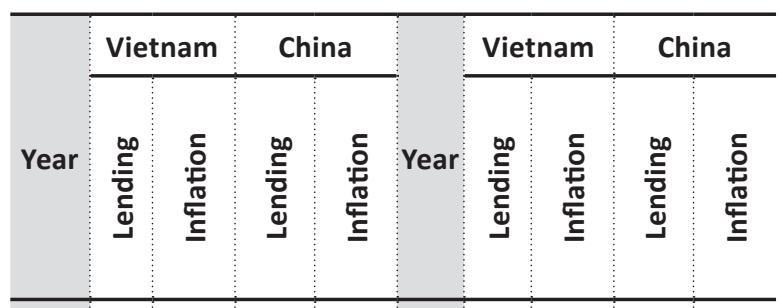


The dataset in Table 1 is intended to analyze and forecast a relationship between the inflation rate and lending rate; In case of inflation, the government should control monetary policy to grow the GDP.

The regression model and cointegration test are designed to find optimal inflation and government control over bad debts when lending rate grows. The impact of the lending rate and inflation rate is analyzed, the model effectively predicts the impact of inflation on GDP. The results are described in the section below.

\section{RESULTS}

The results in this section are presented by the estimation model according to the methodology and dataset from the previous section. The bivariate analysis model is designed to carefully consider the relationship between the lending and inflation rate and determine the true relationship between the two variables to find their impact on GDP growth in Vietnam and China. Otherwise, research results from Vietnam and China are compared to find which entities are most effective in lending capital for economic growth through the impact of lending on inflation. To consider the lag of the model, a unit root test is applied to the model (see Table 2).

As the lending and inflation rate models of China, Vietnam's lending and inflation rate models are applied using the zero-degree difference test.

The results in Tables 2 and 3 show only null hypothesis: China's lending rate has a lag and the remaining results are non-stationary. Therefore, they are then applied through the first-degree difference test.

Vietnam's model has no lag at the zero-degree difference. Hence, this model is also continued to be applied using the first-degree difference test.

Table 2. Inflation: 0-degree difference test - I(0)

\begin{tabular}{|c|c|c|c|c|}
\hline \multirow{2}{*}{ Model } & \multicolumn{2}{|c|}{ China } & \multicolumn{2}{|c|}{ Vietnam } \\
\hline & t-statistic & Prob.* & t-statistic & Prob.* \\
\hline Augmented Dickey-Fuller test statistic & -2.119883 & 0.5031 & -3.651751 & 0.0494 \\
\hline $1 \%$ level & -4.532598 & - & -4.467895 & - \\
\hline $5 \%$ level & -3.673616 & - & -3.644963 & - \\
\hline $10 \%$ level & -3.277364 & - & -3.261452 & - \\
\hline
\end{tabular}

Note: *MacKinnon (1996) one-sided p-values.

Table 3. Lending rates: 0 -degree difference test $-I(0)$

\begin{tabular}{|c|c|c|c|c|}
\hline \multirow{2}{*}{ Model } & \multicolumn{2}{|c|}{ China } & \multicolumn{2}{|c|}{ Vietnam } \\
\hline & t-statistic & Prob.* & t-statistic & Prob.* \\
\hline Augmented Dickey-Fuller test statistic & -2.949767 & 0.1682 & -2.870206 & 0.1907 \\
\hline $1 \%$ level & -4.467895 & - & -4.467895 & - \\
\hline $5 \%$ level & -3.644963 & - & -3.644963 & - \\
\hline $10 \%$ level & -3.261452 & - & -3.261452 & - \\
\hline
\end{tabular}

Note: *MacKinnon (1996) one-sided p-values.

Table 4. China's inflation rate: first-degree difference test - I(1)

\begin{tabular}{|c|c|c|c|}
\hline \multicolumn{2}{|c|}{ Model } & t-statistic & Prob.* \\
\hline \multicolumn{2}{|c|}{ Augmented Dickey-Fuller test statistic } & -6.046190 & 0.0006 \\
\hline \multirow{3}{*}{ Test critical values } & 1\% level & -4.532598 & - \\
\hline & $5 \%$ level & -3.673616 & - \\
\hline & $10 \%$ level & -3.277364 & - \\
\hline
\end{tabular}

Note: * MacKinnon (1996) one-sided p-values. 
Table 5. Vietnam's lending interest and inflation rate: first-degree difference tests I(1)

\begin{tabular}{|c|c|c|c|c|}
\hline \multirow{2}{*}{ Model } & \multicolumn{2}{|c|}{ Lending rate } & \multicolumn{2}{|c|}{ Inflation rate } \\
\hline & t- statistic & Prob.* & t- statistic & Prob.* \\
\hline Augmented Dickey-Fuller test statistic & -5.304932 & 0.0020 & -5.621170 & 0.0012 \\
\hline $1 \%$ level & -4.498307 & - & -4.532598 & - \\
\hline $5 \%$ level & -3.658446 & - & -3.673616 & - \\
\hline $10 \%$ level & -3.268973 & - & -3.277364 & - \\
\hline
\end{tabular}

Note: * MacKinnon (1996) one-sided p-values.

Table 6. Test result for cointegration of inflation and lending rates in China

\begin{tabular}{|c|c|c|c|c|c|c|c|c|}
\hline \multirow{3}{*}{$\begin{array}{l}\text { Hypothesized } \\
\text { no. of CE(s) }\end{array}$} & \multicolumn{4}{|c|}{ China } & \multicolumn{4}{|c|}{ Vietnam } \\
\hline & \multirow{2}{*}{ Eigenvalue } & Trace & 0.05 & \multirow{2}{*}{ Prob.** } & \multirow{2}{*}{ Eigenvalue } & Trace & 0.05 & \multirow{2}{*}{ Prob.** } \\
\hline & & Statistic & Critical value & & & Statistic & Critical value & \\
\hline None * & 0.945642 & 68.99418 & 25.87211 & 0.0000 & 0.698847 & 33.01967 & 25.87211 & 0.0054 \\
\hline At most $1 *$ & 0.682196 & 19.48744 & 12.51798 & 0.0029 & 0.523933 & 12.61734 & 12.51798 & 0.0481 \\
\hline
\end{tabular}

Note: Trace test indicates 2 cointegrating eqn(s) at the 0.05 level; * denotes rejection of the hypothesis at the 0.05 level; ** MacKinnon-Haug-Michelis (1999) p-values.

The results of the lag test show that the time series is stationary at the zero-degree difference $\mathrm{I}(0)$ and the first-degree difference I(I) when the mean, variance and covariance are unchanged at different lags. In addition, this sequence tends to move around the mean. The result of this unit test is the basis for considering co-integration (see Table 6).

It is known that the purpose of the Pearson correlation test is to determine the close linear correlation between dependent and independent variables since the condition for the regression is the first correlation evaluation.
Otherwise, analysis of variance (ANOVA) is a statistical method for analyzing the total variability of dependent variables into multiple parts, and each part is attributed to the variation of an individual interpretation variable or a group of explanatory variables.

In addition, the coefficient table (Table 9) is intended to determine the normalized beta regression coefficients column, the Sig value column. These results indicate whether the data conditions are appropriate for the model.

Table 7. Correlation between inflation and lending rates in China

Source: Author's analysis.

\begin{tabular}{|c|c|c|c|c|c|}
\hline \multirow{2}{*}{\multicolumn{2}{|c|}{ Model }} & \multicolumn{2}{|r|}{ China } & \multicolumn{2}{|r|}{ Vietnam } \\
\hline & & \multirow{2}{*}{$\frac{\text { Inflation }}{1.000}$} & \multirow{2}{*}{$\begin{array}{c}\text { Lending interest rate } \\
0.543\end{array}$} & \multirow{2}{*}{$\frac{\text { Inflation }}{1.000}$} & \multirow{2}{*}{$\frac{\text { Lending interest rate }}{0.552}$} \\
\hline Pearson & Inflation rate & & & & \\
\hline Correlation & Lending rate & 0.543 & 1.000 & 0.552 & 1.000 \\
\hline \multirow{2}{*}{ Sig. (1-tailed) } & Inflation rate & 0.000 & 0.005 & 0.000 & 0.004 \\
\hline & Lending rate & 0.005 & 0.000 & 0.004 & 0.000 \\
\hline \multirow{2}{*}{$\mathrm{N}$} & Lending rate & 22 & 22 & 22 & 22 \\
\hline & Lending rate & 22 & 22 & 22 & 22 \\
\hline
\end{tabular}

Table 8. China's and Vietnam's ANOVA a of lending interest and inflation rates

Source: Author's analysis.

\begin{tabular}{|c|c|c|c|c|c|c|c|c|c|c|}
\hline \multirow[b]{2}{*}{ Model } & \multicolumn{5}{|c|}{ China } & \multicolumn{5}{|c|}{ Vietnam } \\
\hline & $\begin{array}{l}\text { Sum of } \\
\text { squares }\end{array}$ & df & $\begin{array}{c}\text { Mean } \\
\text { square }\end{array}$ & $\mathbf{F}$ & Sig. & $\begin{array}{l}\text { Sum of } \\
\text { squares }\end{array}$ & df & $\begin{array}{c}\text { Mean } \\
\text { square }\end{array}$ & $\mathbf{F}$ & Sig. \\
\hline Regression & 35.577 & 1 & 35.577 & 8.342 & $0.009^{b}$ & 198.437 & 1 & 198.437 & 8.763 & $0.008^{b}$ \\
\hline Residual & 85.295 & 20 & 4.265 & - & - & 452.894 & 20 & 22.645 & - & - \\
\hline Total & 120.871 & 21 & - & - & & 651.331 & 21 & - & - & - \\
\hline
\end{tabular}

Note: a. Dependent variable: China's inflation rate; b. Predictors: (Constant), China's lending rate. 
Table 9. China's and Vietnam's coefficients ${ }^{\mathrm{a}}$ of inflation and lending rates

Source: Author's analysis.

\begin{tabular}{|c|c|c|c|c|c|c|c|c|}
\hline & \multirow{2}{*}{ Model } & \multicolumn{2}{|c|}{$\begin{array}{l}\text { Unstandardized } \\
\text { coefficients }\end{array}$} & \multirow{2}{*}{$\begin{array}{c}\begin{array}{c}\text { Standardized } \\
\text { coefficients }\end{array} \\
\text { Beta } \\
\end{array}$} & \multirow{2}{*}{$\mathbf{t}$} & \multirow{2}{*}{ Sig. } & \multicolumn{2}{|c|}{$95.0 \%$ Confidence interval for B } \\
\hline & & B & Std. error & & & & Lower bound & Upper bound \\
\hline & \multicolumn{8}{|c|}{ China } \\
\hline \multirow{2}{*}{1} & (Constant) & -3.665 & 2.081 & & -1.761 & 0.093 & -8.005 & 0.675 \\
\hline & Lending rate & 0.981 & .340 & 0.543 & 2.888 & 0.009 & 0.273 & 1.690 \\
\hline \multicolumn{9}{|c|}{ a. Dependent variable: China's inflation rate } \\
\hline \multicolumn{9}{|c|}{ Vietnam } \\
\hline \multirow{2}{*}{2} & (Constant) & -3.934 & 3.663 & & -1.074 & .296 & -11.574 & 3.706 \\
\hline & Lending rate & 0.909 & 0.307 & 0.552 & 2.960 & .008 & 0.269 & 1.550 \\
\hline
\end{tabular}

Note: a. Dependent variable: Vietnam's inflation rate.

Firstly, for the sig value tests for each independent variable, the sig is less than or equal to 0.05 , meaning that the variable is significant in the model, whereas the sig is greater than 0.05 , which means that the independent variable needs to be removed.

Secondly, for Beta standardized regression coefficients, in all regression coefficients, the independent variables have the largest Beta, most variables affect the change in dependent variables. Therefore, when proposing solutions, the forecast model is focused more on factors that have large Beta. Besides, the Beta unstandardized regression coefficient indicates that each independent variable changes; this leads to changes in dependent variables. Statistical tests, such as T-test, variance analysis and linear regression analysis above, also require tests of normal distribution or standard deviation. The results of statistical analysis are the basis for setting China's forecast model for the inflation rate and lending rate:

$$
\widehat{Y_{\ln f}}=-3.665+0.9814 X_{\text {Lending }} .
$$

The results of statistical analysis are also the basis for setting Vietnam's forecast model for the inflation rate and lending rate:

$$
\widehat{Y_{\text {Inf }}}=-3.934+0.9095 X_{\text {Lending }} \text {. }
$$

The analysis results are the basis for assessing the issues that will be discussed in the next section.

\section{DISCUSSION}

Inflation has a direct impact on GDP growth, so the determination of the lending rate causes in- flation. This also means that the lending rate affects GDP growth through an appropriate lending threshold. If it exceeds this threshold, it will cause inflation, i.e., GDP growth slows down and is even negative. Therefore, the forecast models are suitable for the economic growth of two countries (Vietnam and China), so that scholars and macro-managers can refer to experimental results and highly reliable data. The discussion is based on the problems data compliance with the models, the optimal lending rate and assessing the impact of inflation on economic growth through the forecast models.

The methodological section has argued about spurious linear regression models. Therefore, the stationarity of the two countries' inflation and lending rate models are empirically tested using the root unit. Hereby, the results in Tables 2 and 3 show that the model is tested with the zero-de. gree difference at the significance level of $1 \%, 5 \%$ and $10 \%$, it gives the following results.

The result of the inflation time series in China is non-stationary at three significance levels of $1 \%$, $5 \%$ and $10 \%$, but the result of the time series of lending rate is lagging at three significance levels of $1 \%, 5 \%$ and $10 \%$, i.e., value-sig is equal to 0.0494 , which is less than p-value 0.05 , and test critical values are less than the augmented Dickey-Fuller test statistic. This leads to be non-tested at first-degree difference. However, Vietnam's empirical inflation rate and lending rate results are non-stationary at three significance levels of $1 \%, 5 \%$ and $10 \%$, i.e. test critical values are larger than the augmented Dickey-Fuller test statistic and $p=0.1682>0.05$; therefore, the empirical results are non-stationary, 
they are tested at the first-degree difference such as empirical results in Tables 4 and 5. Empirical results in Table 4 and Table 5 show that all variables in the models are lags at the significance levels of $1 \%, 5 \%$ and $10 \%$, i.e. the two countries' time series data fit the models. These empirical results are the basis for testing cointegration such as cointegration test results in Table 6 and Table 7. Results for China show that the trace test indicates 2 cointegration at the 0.05 level, i.e., trace statistic of 68,99418 and 19.48744 are larger than the critical value of 25.87211 and 12.51798 , respectively. Vietnam's results also show that the trace test indicates 2 cointegration at the 0.05 level because the trace statistic is 33.01967 and 12.61734 that is larger than the critical value of 25.87211 and 12.51798 , leading to the acceptance of $H_{1}$ hypothesis.

The above empirical results show that two linear regression models are not spurious linear regressions. Besides, other hypotheses have been tested such as two-variable correlation testing, variance analysis and predictive model results. The results in Table 7 indicate that the correlation between inflation and lending rates of the two countries is relatively tight, the correlation of China is 54.3\%, and the correlation of Vietnam is $55.2 \%$, i.e., the factors causing inflation include the lending rate, but the lending rate is with very high proportion, which is $55.2 \%$ and $54.3 \%$. This shows that the lending rate has a significant and positive impact on inflation. This means that if the lending rate increases, the inflation rate also increases.

To assess the suitability of the data for the models, the results also indicate the sum of R-square of $120.872 \%$, and the value of the Sig column in China's ANOVA table shows Sig: $p=0.009$ leading to $P<0.05$, it is statistically significant, thus, $H_{1}$ is accepted. The table of Vietnam's ANOVA also shows statistical significance because $p=0.008, p$ $>0.05 ; H_{1}$ is accepted. The linear regression model by the OLS method is implemented with some assumptions, and the model is only meaningful when these assumptions are appropriate. Hence, to consider the model's reliability, it is necessary to detection violation of assumptions. Therefore, the model is tested using the assumption of a normal distribution of residuals and a linear relationship. The results show that standardized residuals are distributed according to the shape of the normal distribution. There is a bell curve on the histogram that is the normal distribution line, the histogram curve corresponds to that bell curve. Otherwise, mean values are $-2.12 \mathrm{E}-16$ and $-2.71 \mathrm{E} 16$ which are approximately 0 , and the standard deviation is 0.951 , which is approximately 1 , this confirms that the normalized residuals follow a normal distribution, leading to an accepted $H_{1}$ (Dinh, 2019b).

The results in Table 9 also show that China's correlation coefficient is $\hat{\beta}$ (slope), such as: $\hat{\beta}_{2}$ $=0.982$ and the intersection at the vertical axis is $\hat{\beta}_{1}=-3.665$, and Vietnam's correlation coefficient is also $\hat{\beta}$ (slope) such as: $\hat{\beta}_{2}=0.910$ and the intersection at the vertical axis is $\hat{\beta}_{1}$ $=-3.934$. According to the forecast models of the two countries, the lending rate has not yet affected inflation. If one assumes that lending rates of the two countries will increase five times, China's inflation rate forecast will increase to $0.263 \%$ and Vietnam's inflation rate forecast will increase to $-0.294 \%$. This result shows that the capital lending rate of intermediate financial institutions has not yet reached the optimal level.

\section{CONCLUSION}

Empirical results show that inflation and lending rates are closely related and interact with each other. The lower lending rate has led to an increase in the amount of money in circulation, leading to higher inflation in the short term as borrowers borrow more money from those banks to invest. In the short term, they have ineffective investment, leading to a faster-increased quantity of money ratio in circulation than ratio of goods and services; this leads to an increase in the inflation rate. However, in the long term, the inflation rate will be stable again when they effectively invest loan capital (Mishkin, 2016). Therefore, to keep inflation at the appropriate level for the economy, the Government needs to apply a monetary policy to reasonably adjust the lending rate in order to keep inflation in line with the government's targets. 
The research results have found that the interest rate plays an important role in economic growth. It also causes inflation to rise. This means that the lending rate can also ensure sustainable economic growth when loan capital is used effectively, and in the case of inefficient use of loan capital, it can also cause an economic crisis. Based on the Vietnamese and Chinese models, it was found that if the interest rate increases over 3,665 times and 3,934 times, the inflation rate will increase, because the alpha coefficient of the model is negative, and the beta coefficient shows that the lending rate and the inflation rate are positive together. This means that if the interest rate increases more than five times, the inflation rate increases.

Although the economies of Vietnam and China are similar, the lending rates of the two countries affect inflation in different ways. While Vietnam's lending rate affects the immediate inflation rate, China's lending rate does not affect the immediate inflation rate, it influences the inflation rate one year later. This difference in impact is due to the price stability of China's appropriate monetary policy. Besides, they effectively invest through loans from banks. Experimental results have shown that the efficient use of loan capital is necessary, and the loan must be invested consistently with the economic growth of each country.

The Government has a policy requiring commercial banks to strictly control credit risk when financing customers. Besides, the government restricts and focuses on bad debts through the implementation of a tight monetary base by adjusting the basic interest rate. The adjustment of the basic interest rate has led to an increase in the deposit and lending rates. This forces commercial banks to strictly select borrowers, focus on reputable customers in order to conduct efficient business operations, have high profitability rates and high profitability.

\section{AUTHOR CONTRIBUTIONS}

Formal analysis: Doan Van Dinh.

Investigation: Doan Van Dinh.

Methodology: Doan Van Dinh.

Validation: Doan Van Dinh.

Writing - original draft: Doan Van Dinh.

\section{REFERENCES}

1. Aimal, M., \& Meetra, R. (2018). Causal Relationship between Interest Rate and Inflation Rate: A study of SAARC Economies. Kardan Journal of Economics and Management Sciences, 1(2), 157169. Retrieved from https://kardan. edu.af/data/public/files/issue2aimalmirza-meetrarashidi.pdf

2. Amalendu, B. (2016). How Inflation and Interest Rates Are Related to Economic Growth? A Case of India. Journal of Finance and Accounting, 4(1), 20-26. Retrieved from http://pubs.sciepub.com/jfa/4/1/3

3. Apergis, N., \& Eleftheriou, S. (2002). Interest rates, inflation, and stock prices: the case of the
Athens Stock Exchange. Journal of Policy Modeling, 24(3), 231-236. http://doi.org/10.1016/S01618938(02)00105-9

4. Berument, H., Kilinc, Z., \& Ozlale, U. (2005). THE MISSING LINK BETWEEN INFLATION UNCERTAINTY AND INTEREST RATES. Scottish Journal of Political Economy, 52(2), 222-241. http://doi.org/10.1111/ j.0036-9292.2005.00342.x

5. Chowdhury, E. K. (2012). Impact of Inflation on Bank Lending Rates in Bangladesh. Journal of Politics \& Governance, 1(1), 5-13. Retrieved from http://jpg.net.in/ wp-content/uploads/2016/01/JPGVol.-1-No.-1-March-2012.pdf
6. Dinh, D. V. (2019a). Analysed Money Supply and Inflation: Evidence from Vietnam Economy. Advances and Applications in Statistics, 56(2), 125-142. http://doi. org/10.17654/AS056020125

7. Dinh, D. V. (2019b). Money supply and inflation impact on economic growth. Journal of Financial Economic Policy, 12(1), 121-136. http://doi.org/10.1108/JFEP-102018-0152

8. Dinh, D. V. (2020a). Optimal Inflation Threshold and Economic Growth: Ordinal Regression Model Analysis. The Journal of Asian Finance, Economics and Business, 7(5), 91-102. http://doi. org/10.13106/jafeb.2020.vol7. no5.091 
9. Dinh, D. V. (2020b). Forecasting domestic credit growth based on ARIMA model: Evidence from Vietnam and China. Management Science Letters, 10(5), 10011010. http://doi.org/10.5267/j. msl.2019.11.010

10. Dinh, D. V. (2020c). Impulse Response of Inflation to Economic Growth Dynamics: VAR Model Analysis. The Journal of Asian Finance, Economics and Business, 7(9), 219-228. https:// doi.org/10.13106/jafeb.2020.vol7. no9.219

11. Garín, J., Lester, R., \& Sims E. (2016). Raise Rates to Raise Inflation? Neo-Fisherianism in the New Keynesian Model (NBER Working Paper No. 22177). http:// doi.org/10.3386/w22177

12. Hamidah, R., \& Mohd, S. I. (2017). The Relationship Between Interest Rates and Inflation Toward the Economic Growth in Malaysia. Journal of Humanities, Language, Culture and Business, 1(1), 5563. Retrieved from http://www. icohlcb.com/images/Articles/ Vol_1/Paper-006-.pdf
13. Jiménez, G., Ongena, S., Peydró, J.-L., \& Saurina, J. (2012). Credit Supply and Monetary Policy: Identifying the Bank BalanceSheet Channel with Loan Applications. American Economic Review, 102(5), 2301-2326. http:// doi.org/10.1257/aer.102.5.2301

14. Kaplan, F., \& Gungor, S. (2017). The Relationship Between Money Supply, Interest Rate and Inflation Rate: an Endogeneity-Exogeneity Approach. European Scientific Journal, 13(1), 30-38. http://doi. org/10.19044/esj.2017.v13n1p30

15. Khumalo, L., Mutambara, E., \& Assensoh-Kodua, A. (2017). Relationship between inflation and interest rates in Swaziland revisited. Banks and Bank Systems, 12(4), 218-226. Banks and Bank Systems, 12(4), 218-226. http://doi. org/10.21511/bbs.12(4-1).2017.10

16. Md. Kamal, Uddin, \& Saima Umme, (2015). Causal Relationship between Lending Rate and Deposit Rate in Bangladesh: An Econometric Analysis. IOSR Journal of
Economics and Finance, 6(6), 41-47. Retrieved from http:// www.iosrjournals.org/iosr-jef/ papers/Vol6-Issue6/Version-2/ E06624147.pdf

17. Mishkin, F. (2016). The Economics of Money, Banking and Financial Markets. Columbia University, United State: Addison-Wesley of PEARSON.

18. Moroşan, G., \& Zubaş, I. M. (2015). Interest Rate, Exchange Rate and Inflation in Romania. Correlates and Interconnection. Journal of Public Administration, Finance and Law, 4(8), 146-160. Retrieved from http://www. jopafl.com/uploads/issue8/INTEREST_RATE_EXCHANGE_ RATE_AND_INFLATION_IN_ ROMANIA.pdf

19. Tillmann, P. (2008). Do interest rates drive inflation dynamics? An analysis of the cost channel of monetary transmission. Journal of Economic Dynamics \& Control, 32(9), 2723-2744. http://doi. org/10.1016/j.jedc.2007.10.005 